\title{
Failure for Status of the War Participation Army of Beiyang government
}

\author{
Shihong Song \\ Department of History, Sichuan University, Chengdu, China
}

Keywords: The War Participation Army; Duan Qi-Rui; Beiyang Government.

\begin{abstract}
There is an old saying "name is not the regular word, the word is not good". Since ancient times, people in China have been pursuing the right and proper attitude. So have the people in the republic of China. But there is such exceptions as the war participation army of Beiyang government. The setting up of War army has something to do with both Duan Chi-jui personal purpose and Japan. The nature of the army goes to illegal and nonsense. At the beginning of the setting up, the army has been widely questioned and required to cancel from all walks of life. Duan qi-rui tried to be "right", but failed in the Zhihuan war in the end.
\end{abstract}

\section{Introduction}

The war participation army in the period of Beiyang was a team formed to participate in a war important military force, which was called "the crown". The setting up of the army, has aroused strong repercussions at that time. But it is necessary to explore the reasons why the army was questioned by all circles at the beginning of its emergence. The research on the belligerent army during the Northern Warlords period is not uncommon, but most of them are studies on the Northern Warlords clique, the Anhui clique or individual research of Duan Qirui. Therefore the single study of the participating army is rare. Based on the previous research results, this paper focuses on the set up, ownership, renamed reason and the fall of the army.

During the World War 1, the Beiyang government organized the army for the purpose of particip ating in the First World War after declaring war on Germany in August 1917. Although the army w as established under the pretext of participating in the First World War, it was a completely subordi nate private army under Duan Qirui's needs for political struggle. In December 1917, Duan Qirui to ok over the supervision of the participating war office and entered into war loans with Japan. Japan provided arms and instructors and gradually began to train the participating war armies.

The troops were from Henan, Shandong and Anhui. There were three battalion soldiers, and Qu TongFeng, Ma Liang, and Chen Wenyun served as commanders. After the end of World War I, the participating warships degenerated their external functions and their internal functions were strengthened.The main merit of the army is to obtain deterrence to the Mongolian self-government and force it to cancel its autonomy. Due to the factional political struggles in the country, Duan Qirui's militants were defeated in the 1920 Wan-Anhui War and were later reorganized by Direct and Fengxian warlords.

\section{Formation of the War Participation Army}

Duan Qiarui , the founder of the war army, was one of the three outstanding persons of the Northern Warlords and also the leader of the Huan army. served as the chief of the army, the prime minister and the general administration successively. Although he was from the army, Duan had a lack of armed forces since he hold a post in the central organs. Duan was well aware of the importance of military power in the early years of Republic of China when there were a number of political struggles and turmoil. That is to say, without the army, he would stumble and struggle in a central political battle. In response to battle between government and court, ZhangXun restoration and "force practice ", Duan knew deeply that you can do nothing without military power . So it is very necessary to train and control an army which completely belongs to him. After the first World War, with the 
changes of the international situation, there were two parts in the Northern Warlords government around the issue of participating the war. One was war party led by Duan Qirui. The other one was opposition party led by LiYuanhong. After several battles, in August 4, 1917, the Northern government declared war on Germany and Austria and joined the Entente countries, which provided an opportunity for Duan. However, by the end of November of 1917, there were the internal contradictions in the Beiyang government, and Duan Qirui resigned as prime minister. But Feng Guozhang , the acting president, was unable to control the Huan forces, which gave rise to internal conflicts. At the same time, the Russian Revolution broke out in October, and the Soviet Union left the first World War, which changed the international situation. Feng Guozhang could not help but be a bit scared" because the war prospect is confusing and it might be wrong to join the war. On this occasion with troubles internally and externally, Feng had to recommission Mr Duan Qirui which could throw the tight problems to Duan and ease the contradiction between the Zhi and Huan. Therefore, Feng Guozhang appointed Duan Qirui as supervisor of the war affairs office in December 18, 1917, and Duan was responsible for all matters related to the war.

After the October Revolution in Russia, Japan paid more attention to the situation in the Far East. In order to prevent the eastern invasion of German and Austro Hungarian Empire forces through Siberia, Japan proposed the signing of agreement of Sino Japanese anti enemy of the military to the government with Beijing government. In February 1918, Japan took another excuse that Russia was in bad shape with the United nations...... China's national defense is tight, that is, Japan's national defense is tight, and then put forward the requirements of Sino Japanese common defense. Because of the domestic political struggles, Duan Qirui's also needed the support and assistance from Japan. Then under the leadership of Duan, a series of agreements have been made after the negotiations of relevant departments. The Japanese War army agreement has been signed ince then, under the economic and military support of Japan, the formation of the armed forces has gradually kicked off.

\section{The Ownership of The Army And Caused Opposition}

In February 25, 1918, the Beijing government announced the " Supervision Organization of War Office". According to the announcement, the war office directly under the administration of the president, which is a temporary and independent institution set up because of the war, not belonging to the cabinet or the department of the army and the ministry. The war participation army formed in the name of war was only under the jurisdiction of the war affairs office and the supervision of the war, not belonging to the army department.

Because the war affairs involved various government departments, the war office had more superior right than Prime Minister of giving instructions to cabinet departments, troops, even foreign affairs . What's more, the operation of rights is outside the government system. In March 1, 1918, the office of the war affairs supervision was established. The next day, Duan Qirui made announcement to the military and political officials that due to the tight military situation all war events should be submitted this office immediately which gave rise to the special status and identity of both the war office and the participating army.

It is no difficulty to find that either the War Office or the army was informal, but both of them had more privileges than those formal ones. As a result, all parties have questioned and denied them since the establishment of armed forces and the office. In addition, the participating army was formed in January 1919 when World War I was over. It was even more improper. All parties both at home and abroad were intolerant of their independence and unanimously requested that they be canceled or return to the Army Department.

In December 1917, Duan Qirui was appointed as the chief commander of the war office , which was opposed by the governor of Yunnan, Tang Jiyao and Guangxi Warlord Tan Haoming. They required to rescind the appointment and pointed out that the Presidents commander-in-chief of the navy and the army, having the right of declaring war or making pace according to the Provisional Law. What the office has done was against to the spirit of the Provisional Law and lacked the basis of order.

Both the various factions and all sectors of society have denounced it. The militants directly related with Japan. People regarded it as the "private army" of Duan Qirui, who was trained in Japan's 
loans, ordnance, consultants and training modes. In order to obtain the support of Japan, Huan forces led by Duan sacrificed some sovereignty over various agreements between China and Japan. Therefore, when the news of the Sino-Japanese agreement was disclosed, there were public outcry in the country. Some newspapers said that the army is organized by foreign traitors for communication with foreign traitors. The Chinese people will meet with their dead and oppose it. The military will remain unshaken. Is no different from their opposition to the goal, to increase the security for the traitor, since the fate of the world. Because of its close relations with Japan, people have called for an end to the Sino-Japanese borrowing, the cancellation of the agreement, the demobilization of troops.

What's more, the international community also holds a negative attitude toward the existence of the participating war armies. In March 1919, the Anglo-American ambassador to China met with Chen Kui, Beijing's chief representative, and put forward the opinion of canceling the participation of the militants. In November, the U.S. and British ambassadors also ordered their government to cancel the militants.

\section{Attempts to Resolve the Fame - Renamed the Army}

In January 1919 when the World War 1 was over, the participated army organized. The original purpose of setting up the army was obviously not even more plausible. Duan Qirui also realized this point. But it is impossible to hand such a well-equipped and devoted training army over other people. In order to cope with this change and to solve the situation that the militiamen have been criticized by the public opinion, Duan have renamed it as the "National Defense Force". He intended to achieve the "correct name" of the army. However, after being renamed, the army was still being requires of abolition , which forced Duan to find another way to make it proper.

As early as October 1918, Duan Qirui excused the unstable northwest frontier and set up a Northwest Frontier Preparatory Office under the war office. Xu Shuzheng, the director of the office, was responsible for practicing the Northwest Frontier Defense Force. After World War I, due to the more inadequate rationality of the presence of the participating war offices and the participation of war-wielding troops, and the continuous intimidation by various forces both at home and abroad, Duan Qirui made President Xu Shichang abolish the war office and set up the border office. So Duan served as the supervisor of the border office. In August, the battleships under the jurisdiction of the People's Liberation Army (previously renamed as IDF) were all changed to border guards. As a result, changes in the rank and file of the participating militias were preserved and their status as "legal" and "reasonable" was retained. However, in the eyes of the people, whether they are participating militaries, the IDF or the border guards, they all belong to the nature of Duan Qirui's "private army" and have always been difficult to change. Although it has been hard for them to be included in the state system after being replaced by Duan Qirui, Recognized. Although the militias were nominally for the sake of participating in the World War I, the legitimacy and lack of legitimacy have made them "unjust" organizations, constantly striving to oppose them. Although Duan Qi Rui several times changed its name after World War I, it is hard to be recognized .

\section{Conclusion}

The question of the absence of an orthodox "property" as a militant force was without doubt. Although the establishment of the war office was the order from presidential office, there is no legal basis itself. The participating warships affiliated to the office was a lack of property, either. Because the military training, funding, ordnance and training personnel have close ties with Japan, they are the product of the Sino-Japanese agreement. There is more lack of rationality. Duan Qirui relied on such an army that was neither legitimate nor unreasonable. Despite the fact that the equipment, treatment and qualifications of officers and other officers were "the highest in the country", Duan eventually failed with his Wan army. From July 14, 1920 to July 24 when Duan Qi issued the total attack order, less than 10 days, the army ended in defeat. After the war, Duan Qirui was exempted from supervising and handling frontier affairs. The war army and the border defense forces belonging to 
the section were dismissed as well. Therefore, Duan Wan forces completely disintegrated and exited the stage of history, which can be described as "the name is not correct, unspeakable, things fail."

\section{References}

[1] Lai Xinxia. "History of the Northern Warlords", Oriental Publishing Center, 2011.

[2] Guo Jianlin. "Three Civil War North China Documentary", Nankai University Press, 2003.

[3] Rong Meng source, Zhang Bo Feng. "Modern barnyard sea", Sichuan people's Publishing House, 1985.

[4] Zhang Yilin. "Direct Anhui Secret History", Zhonghua Book Company, 2007.

[5] Du Chunhe and other editors. "Northern Warlords Historical Materials" , China. Social Sciences Press, 1981.

[6] Zhang Bo Feng."Northern Warlords 1912--1928" Volume 3, Wuhan Press, 1989. 